CHAPTER I

\title{
Lancelot 'Capability’ Brown: An Eighteenth-Century Life
}

\author{
Jonathan Finch and Jan Woudstra
}

\begin{abstract}
Early Years
Lancelot 'Capability' Brown (1716-83), Britain's most famous gardener and designer, was undeniably a man of his times. His life spanned a period of unprecedented social and economic change, which saw increased investment in the transformation of the English rural landscape: a landscape within which most people lived and earned a living, and a landscape whose ownership determined the political constitution of the country. Yet it was a landscape in flux, with new industrial centres changing how and where people lived and worked, creating new forms of wealth from networks that spanned the globe. Brown's life work was to realise a landscape style attuned to the needs of the social and economic elite, who had consolidated their hold on the levers of power after the political settlements of the late-seventeenth century. Brown's landscapes embodied the aspirations and ideals of those who benefited most from the evolving modern world: landscapes that embodied balance and harmony through the elegance and comfort of beauty.

When Brown was born in Northumberland around 1716, the first stirrings of the modern landscape movement were already being articulated. During the first few years of the eighteenth century most of the literature published on gardens in Britain was either translations or reprints of earlier works. ${ }^{1}$ One of the most significant was John James's The Theory and Practice of Gardening, published in 1712, as a translation of Dézallier d'Argenville's work (1709), which celebrated André le Nôtre’s formal garden style, associated with the French court. ${ }^{2}$ However, the move away from such formalism began with Stephen Switzer's The Nobleman, Gentleman and Gardener's Recreation, published in 1715, which was the foundation for his great work Ichnographia Rustica (1718). ${ }^{3}$ Switzer trained at the Brompton nursery under George London and Henry Wise, as did the designer Charles Bridgeman (d. 1738), whose landscapes popularised the new move towards a greater naturalism, and

\footnotetext{
${ }^{1}$ Blanche, H. (1975). British botanical and horticultural literature before 1800 (Vol. 2, p. 415). Oxford: Oxford University Press.

2 James, J. (1712). The theory and practice of gardening. London; Dézallier d'Argenville, A. J. (1709). La theorie et la pratique du jardinage. Paris.
}

${ }^{3}$ Switzer, S. (1718). The nobleman, gentleman and gardener's recreation. London; Switzer, S. (1718). Ichnographia Rustica. London.
\end{abstract}

How to cite this book chapter:

Finch, J. and Woudstra, J. 2020. Lancelot 'Capability' Brown: An Eighteenth-Century Life. In Finch, J. and Woudstra, J. (Eds.), Capability Brown, Royal Gardener: The business of place-making in Northern Europe, pp. 1-15. York: White Rose University Press. DOI: https://doi.org/10.22599/CapabilityBrown.a. CC BY-NC 4.0 


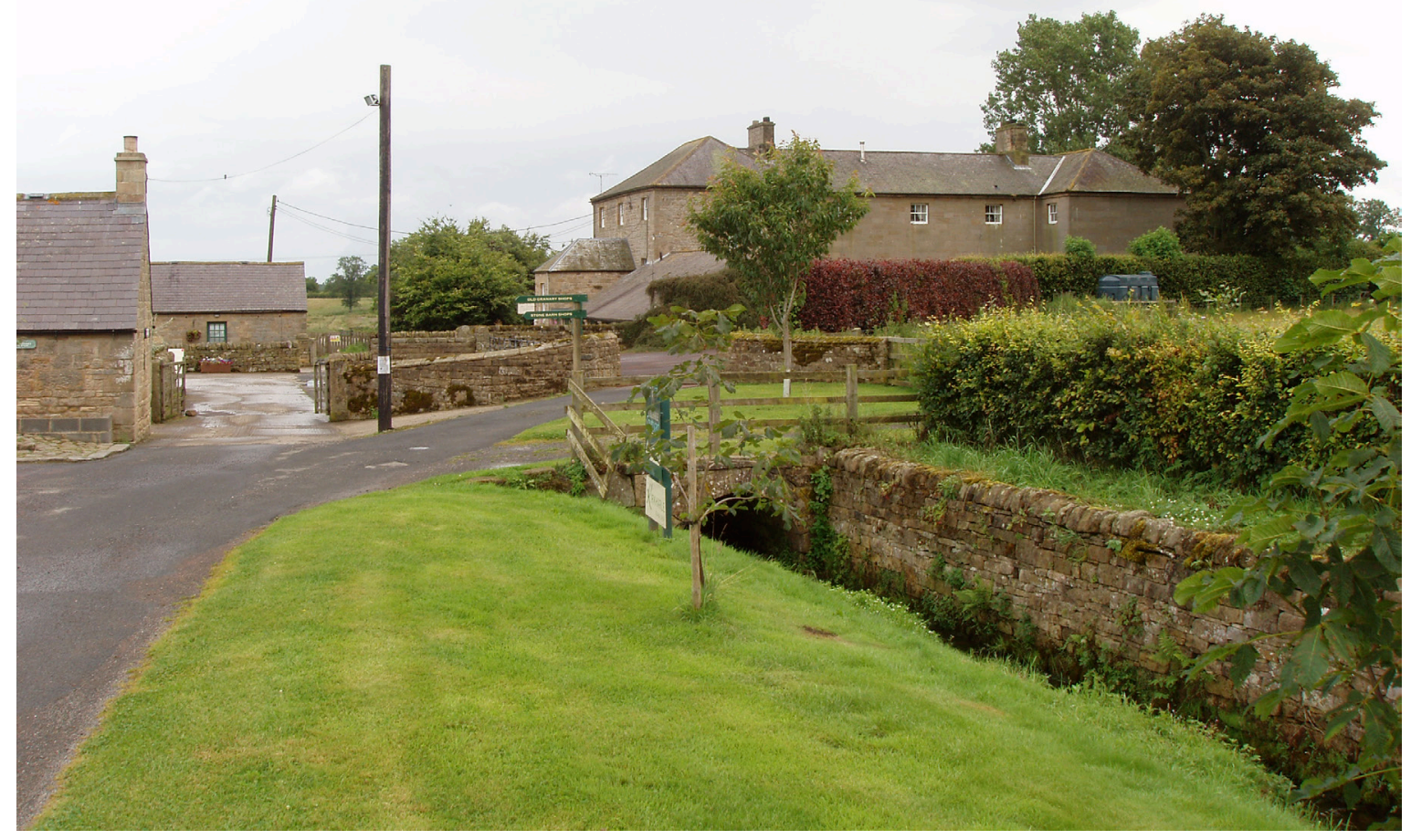

Figure 1.1: Estate buildings, Kirkhale, Northumberland. Brown started his career as an apprentice to the head gardener of Kirkhale, Northumberland, where his father had been a land agent. Photo copyright Jan Woudstra, 2008, CC BY-NC 4.0.

who worked with Alexander Pope, the century's greatest man of letters, on his influential garden and house at Twickenham, and at Marble Hill, Richmond.

Yet Brown's family lived in Kirkhale, in Northumberland, a fairly typical small rural community, over 300 miles to the north, far from the glittering metropolitan world. His father, who died in 1720 when Brown was only four, was a farmer and land agent to the local lord, Sir William Loraine, yet the young Brown was educated at the local school in Cambo - possibly through the good offices of Loraine. Clearly an important family on the estate, Brown's elder brother John became the estate surveyor and married Sir William's daughter, whilst another brother, George, became a mason and architect in neighbouring Wallington, and also married into a local gentry family. Brown started as an apprentice to the head gardener at Kirkhale, where he may also have learned estate management under the tutelage of Loraine, who was a keen improver (Figure 1.1). Brown moved on at the end of the 1730s - probably to Lincolnshire, where it has been suggested he learned engineering and water management, before he appeared in Oxfordshire, from where he was recruited by Lord Cobham to work at the famous gardens of Stowe (Bucks) in 1741. ${ }^{4}$

Brown arrived at Stowe, the epicentre of political and aesthetic change that was transforming designed landscapes, only two years after leaving his home in Kirkhale, suggesting that the distance between a local northern estate and metropolitan society might not have been so far in the mid-eighteenth century. At Wallington, for example, Brown's brother George was mentored by Daniel Garrett, who had been Lord Burlington's clerk of works and was a colleague of William Kent. ${ }^{5}$ Networks of patronage and the growing sense of social mobility amongst the educated and aspirational professional class could open routes to success that had hitherto been

\footnotetext{
${ }^{4}$ Stroud, D. (1950). Capability Brown (p. 29). London: Country Life.

5 See Hill, R. (2012). As God intended. Review in London Review of Books, 34(1). Review of Brown, J. (2011). The omnipotent magician, Lancelot 'Capability' Brown, 1716-1783. London: Chatto and Windus.
} 


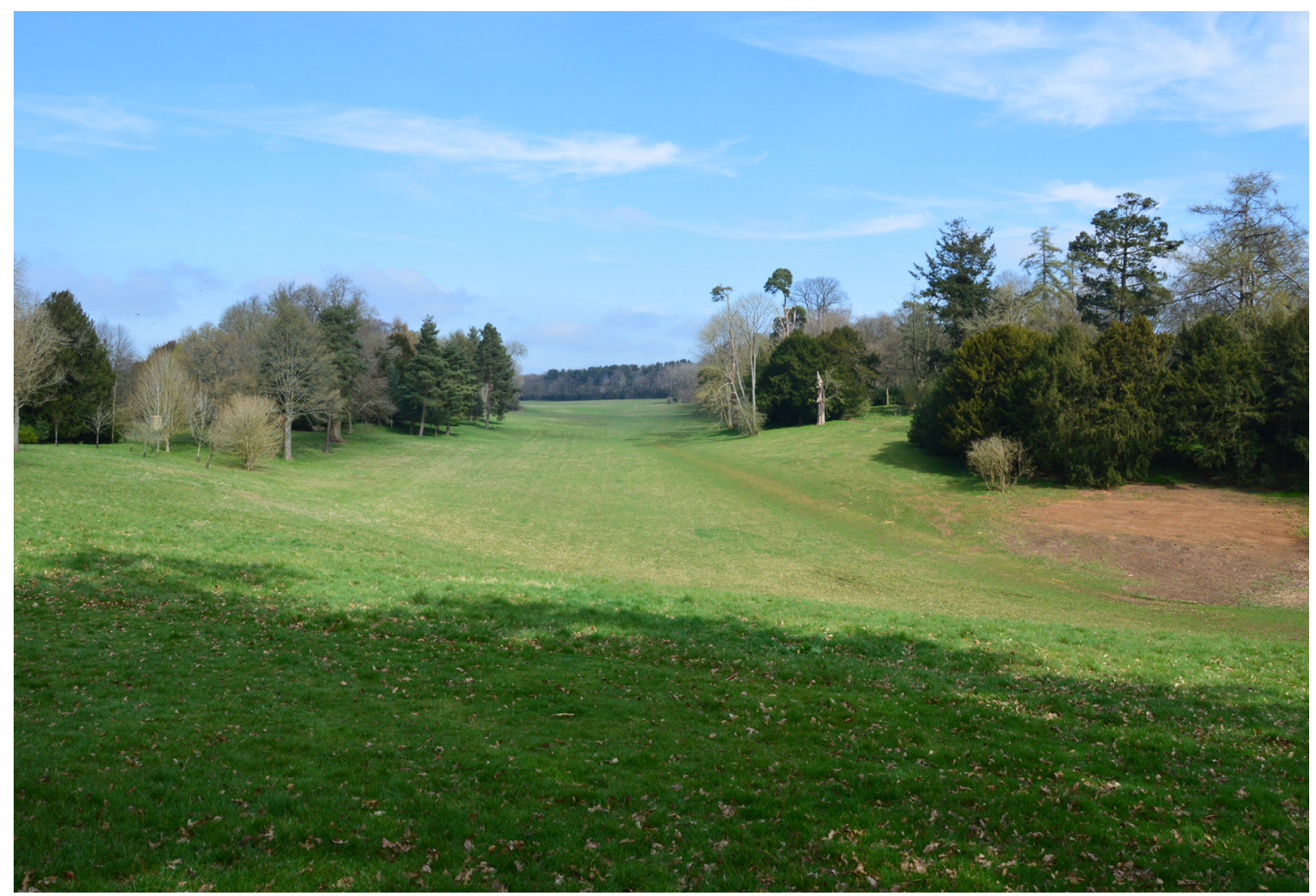

Figure 1.2: Stowe, Bucks. One of the largest innovations at Stowe in c. 1747 was the creation of the Grecian Valley, which had originally been intended to become a lake. Photo copyright Jan Woudstra, 2014, CC BY-NC 4.0.

dependent on the vagaries of court patronage. Lord Cobham's showpiece was already well-established as a landscape of political theatre, with its Temples of Modern and of Ancient Virtue, and the gothic Temple of Liberty all providing a scathing satire on Sir Robert Walpole's political hegemony, which was to collapse the following year, in 1742. The opening out of the political landscape thereafter was to some extent pre-figured by William Kent's landscape vision at Stowe, where he had softened Bridgeman's structural geometry and formalism into a looser, more theatrical style (Figure 1.2).

It is worth briefly comparing Bridgeman and Kent with Brown, as his immediate predecessors. Bridgeman and Kent worked successively at Stowe, where Brown took his first important post, so they undoubtedly loomed large in his professional development and landscape ideas. Bridgeman had worked for London and Wise, and drew strongly on their interpretation of the continental styles popularised by Le Nôtre. Bridgeman's designs integrated informal or naturalistic elements within the framework of geometric formalism, which led Horace Walpole to declare that Bridgeman was responsible for the 'dawn of modern taste' in garden design. ${ }^{6}$ The key innovation for Walpole was the opening out of the garden to the wider landscape through the use of the ha-ha, which brought greater potential and scope to design and a sense of the Picturesque, as conceived by the seventeenth-century artists Claude and Poussin, amongst others, whose work had been popularised by collectors on the Grand Tour. Bridgeman followed in the footsteps of London and Wise, not just in the professional sense of having worked at the Brompton nursery, which itself should never be underestimated as a loci genius for the English landscape style, but also in that he succeeded Wise as royal gardener from 1728 to $1738 .{ }^{7}$ Bridgeman's role at court recognised his position as the foremost designer of his day, as it did latterly for Brown.

\footnotetext{
${ }^{6}$ Walpole, H. (n.d.). The history of modern gardening. In Walpole, H. Anecdotes of painting (Vol. 4, p. 263). London: Ward Lock.

7 Wise had been royal gardener for the first twenty-eight years of the eighteenth century; see Willis, P. (2002). Charles Bridgeman and the English landscape garden (pp. 5-8). Newcastle upon Tyne: Elysium.
} 
Like Brown, Kent had risen from inauspicious origins. Talent-spotted as a coach-painter from Bridlington on the North Yorkshire coast, a group of aristocrats sponsored his sabbatical in Italy, where Kent met the $3^{\text {rd }}$ Earl of Burlington, who became his principal patron on their return to England in 1719. Unlike Brown, Kent's education focused on painting and art, and with Burlington's encouragement he emerged as a talented interior designer and architect in the 1730s, before turning his hand to landscapes, again with influential backing, this time from his long-time friend Alexander Pope. Kent's landscape style developed from an artistic and theatrical foundation, and he worked by providing perspective views of his proposed landscapes rather than the more traditional plans. It was Kent who Walpole famously said 'leaped the fence, and saw that all nature was a garden': Kent extended Bridgeman's sense of naturalism and asymmetry beyond the confines of a geometric frame. ${ }^{8}$

In 1734 Sir Thomas Robinson wrote to his father-in-law, the $3^{\text {rd }}$ Earl of Carlisle, at Castle Howard in North Yorkshire, that 'the new taste in gardening just arisen ... after Mr Kent's notion of gardening' was to 'lay them out, and work without level or line. The desire was for far greater diversity and variety in the design, a rejection of symmetry and as a result it has the appearance of beautiful nature ... one would imagine art had no part in the finishing.' It is perhaps significant in the context of understanding the importance of the court circle to the development of eighteenth-century landscape taste to realise that the commotion Robinson was reporting, the ripples of which would stimulate landscape work across the country, emanated from Kent's reworking of the garden attached to Carlton House for Frederick, Prince of Wales, who had bought it from Lord Burlington in 1732.

Both Bridgeman and Kent can be seen to have laid propitious foundations for Brown. Not only did they initiate the break from geometric formal gardens which remained so popular on the Continent, but they also provided a career path, as royal gardener, and as the socially and critically celebrated landscape designer. Both Bridgeman and Kent were celebrated by their clients for their artistic vision and taste, and for ushering in modern taste. Yet Bridgeman died relatively young, in his late forties, and Kent only designed landscapes from the 1730 s to his death in 1748, a decade after Bridgeman. Thus, arguably, the potential of these two designers was never fully realised within the landscape, and when their great patron Lord Cobham also died, a year after Kent in 1749 , the scene was set for Lancelot 'Capability' Brown to take up the mantle of landscape design.. ${ }^{10}$

\section{Rise to Dominance}

Brown's rise to dominance over the following decades was unprecedented. His reach across the country cannot be denied; he probably worked at well over 200 sites, from Alnwick in Northumberland to Ugbrooke in Devon, and, as a result, over the course of his career his name became inextricably linked to the taste for modern landscapes and what had become the dominant aesthetic of the Beautiful. ${ }^{11}$ By the time he moved to Hammersmith to establish his own practice in the autumn of 1751, perhaps on the advice of the architect Henry Holland and perhaps to target royal patronage, he had already caught the eye of important commentators including Walpole, and had already coined the name 'Capability'. Over the 1750s Brown secured major commissions at Ashridge (1754, Herts), Burghley House (1754, Lincs), Madingley (1756, Cambs), Longleat (1757, Wilts), Wrest Park (1758, Beds), and Burton Constable (before 1760, East Yorks). When Brown visited the site of what would become Harewood House (West Yorks) in 1758 he was in high demand, and the head gardener at Castle Howard wrote to the steward at Harewood asking excitedly if he could forward even 'a few random Pencil Strokes of Mr Brown's Designs for your Place', such was the widespread anticipation caused by a single visit. ${ }^{12}$

\footnotetext{
${ }^{8}$ Williamson, T. (1995). Polite landscapes. Gardens and society in eighteenth-century England (pp. 58-61). Stroud: Alan Sutton.

${ }^{9}$ Historical Manuscripts Commission. (1897). Fifteenth Report, Appendix, Part VI: The manuscripts of the Earl of Carlisle, preserved at Castle Howard (p. 143). London: HMSO.

${ }^{10}$ Burlington died soon after in 1753.

${ }_{11}$ Gregory, J., Spooner, S. \& Williamson, T. (2013). Lancelot ‘Capability’ Brown: A research impact review (Research Report 50) (pp. 7-9). London: English Heritage.

${ }_{12}$ Quoted in Finch, this volume. The landscape at Castle Howard was not extensively remodelled in the late-eighteenth century and is one of the few remaining large landscapes which retain a formal structure, although it has been altered over the years. Nearby Bramham is perhaps the best example.
} 
Brown's timing was fortuitous. The economy was improving as the British global economy gathered pace and by the 1740s much of the new wealth which had accumulated within the elite was being invested in land and building. In 1739, it was noted that:

Every Man now, be his fortune what it will, is to be doing something at his Place, as the fashionable Phrase is; and you hardly meet with any Body, who, after the first Compliments, does not inform you, that he is in Mortar and moving of Earth; the modest terms for Building and Gardening. One large Room, a Serpentine River, and a Wood, are become the most absolute Necessaries of Life, without which a Gentleman of the smallest Fortune thinks he makes no Figure in his Country. ${ }^{13}$ [original emphasis]

Analysis of country house building and alterations to houses shows high rates of investment in building from the late-seventeenth century into the first quarter of the eighteenth, and after a pause in the 1730s a steady rise to a peak in the 1770s. ${ }^{14}$ As new builds or the substantial rebuilding of houses, almost all of these schemes would have included a reworking of the surrounding landscape and an opportunity for Brown and his team over the key period of growth from the 1750s to the 1770s.

Brown's surviving financial accounts corroborate the evidence from building accounts and show that his income grew steadily between 1755 and 1765 , but that it reached its highest peaks in the following decade,

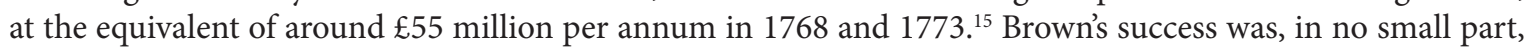
sustained by his business model: he provided a rapid initial site assessment, often verbally after an hour or so around the site on horseback, in which he would sketch out the 'great capabilities' of the place, and then he could provide a detailed plan of the proposed improvements, which, if approved, would be carried out by trusted subcontractors and teams of workers - the 'capability men' - sometimes in combination with the client's own estate workforce. ${ }^{16}$ Brown was thus able to extend his reach across the country as a whole, and could support major concurrent projects - a logistical feat that other designers failed to manage.

Brown notably left no written treatise on his approach to landscape design, but, in a paragraph he wrote to accompany a plan he sent to France at the height of his fame in 1775, he extolled his 'ideas on Gardening and Place-Making':

when [it is] rightly understood will supply all the elegance and all the comforts which Mankind wants in the Country and (I will add) if right, be exactly fit for the owner, the Poet and the Painter. To produce these effects there wants a good plan, good execution, a perfect knowledge of the country and the objects in it, whether natural or artificial, and infinite delicacy in the planting etc., so much Beauty depending on the size of the trees and the colour of their leaves to produce the effect of light and shade so very essential to the perfecting a good plan: as also the hideing what is disagreeable and shewing what is beautifull, getting shade from the large trees and sweets from the smaller sorts of shrubbs etc. ${ }^{17}$

The statement reveals his intention to appeal to the arbiters of taste - the landowners, poets and artists - but significantly it goes on to state that its execution needed to be delivered through the skills of the improver, the surveyor, the steward, the estate manager: skills which Brown had acquired in his youth, in combination with an aesthetic understanding of the landscape itself.

Brown's combination of skills enabled him to place emphasis on the larger scale, on the placement and mass of trees and foliage in clumps and belts, with interest and variety given through light and shade, height, and scale - all illuminated and animated by the play of light on water in the midst. It was the co-ordination of the natural and artificial elements, with as little apparent effort as possible, that perfected nature. It was concord

\footnotetext{
${ }_{13}$ Anon. (1739). Common sense. The Gentleman's Magazine, 9, 640.

${ }^{14}$ Wilson, R. \& Mackley, A. (2000). Creating paradise: The building of the English country house (pp. 199-323). London: Hambledon.

15 Floud, R. (2016). Capable entrepreneur? Lancelot Brown and his finances. Occasional Papers from the RHS Library, 14, 19-41 (p. 27, fig. 4).

${ }^{16}$ See Brown, Finch, Williamson, and Woudstra in this volume.

17 Stroud, D. (1975). Capability Brown (p. 157) (Rev. ed.). London: Faber and Faber.
} 
and harmony brought together by taste, and the effect was captured in an anonymous poem published in 1767 and dedicated to Charles Ingram, $9^{\text {th }}$ Viscount Irvine, who had employed Brown at Temple Newsam near Leeds two years before:

Sweet waving hills, with woods and verdure crown'd

And winding vales, where murmuring streams resound:

Slopes fring'd with oaks which gradual die away,

And all around romantic scenes display.

Delighted still along the park we rove,

Vary'd with hill and dale, with wood and grove:

O'er velvet lawns what noble prospects rise ${ }^{18}$

This extract captures the characteristic elements of Brown's landscapes - the topography, the trees, the lawns, the water - and, importantly, the impact of their dynamic relationships which were experienced (resound/ delighted) as the narrator and their companion 'rove' around the park, enjoying the display of romantic scenes, which later in the poem are compared to the painterly visions of Salvator Rosa (1615-73) and Claude Lorrain (1600-82).

The textual or literary metaphor returns in one of the most frequently quoted passages about Brown's approach to landscape, from a letter by the writer and philanthropist Hannah More (1745-1833), who spent two hours with Brown in the gardens at Hampton Court receiving 'a very agreeable lecture from him in his art' during a particularly clement spell of weather in December 1782. Brown expounded his approach in literary metaphors - explaining how he would mark spots with a comma, more decided turns with a colon, or an interruption with a parenthesis. ${ }^{19}$

Whether or not this was his working practice, it at least demonstrates the importance of the narrative, in the sense of a punctuated flow or movement, through a Brown landscape. Given this link to narrative, to flow, and to the holistic vision of landscape, it is perhaps unfortunate that Brown's landscapes are often characterised as the simple orchestration of key elements - the perimeter belt, irregular clumps of trees, meandering rides or walks, swathes of grass, and an expanse of water in the middle distance. Yet it was when they worked together that these elements realised an imagined or nostalgic landscape for his patrons, even if the constituent parts were familiar from the earlier works of Bridgeman and Kent. Brown's landscapes were the expression of cosmopolitan taste, a classical education, a Grand Tour and a familiarity with fine art, all translated, domesticated, into the English landscape.

The relationship between society and the landscapes it creates has always been complex, but never more so than in the eighteenth century. The majority of the population was still employed in agricultural occupations, and would be for another 100 years, yet in many areas of the country the working landscape was being transformed, with the remnants of medieval open-field systems enclosed into new fieldscapes of modern farms with compact holdings laid out in large regular fields. Amongst the ruling elite, the narrative of 'improvement' had become a national project set against the need for greater self-sufficiency in the face of wars and revolutions in continental Europe, and a political desire to modernise both the economy and society. It was within this broader context that the largest landowners, secure in their position as the ruling class after the political settlements of the late-seventeenth century, created landscapes around their houses and seats, to express and legitimate their power, and it is worth remembering that Brown was often referred to as an 'improver' - both because he employed many of the technical skills associated with agricultural improvement, such as drainage and extensive tree planting, and because his aim was to improve the accidents of nature. The eighteenthcentury concept of nature in this diverges substantially from that of the twenty-first century, and at the time included existing features of landform, trees, and even avenues. These would be improved: shaped and planted not only for beauty but also to provide interest and variety. Of course, there was also the formation of bodies of water, but by envisaging this within the context of wider agricultural improvement it is clear that these were not

\footnotetext{
${ }_{18}$ Anon. (1767). Rise and progress of the present taste in planting parks, pleasure grounds, gardens \&c.: From Henry the Eighth to King George the Third (p. 29). London.

19 Roberts, W. (Ed.) (1834). Memoirs of the life and correspondence of Mrs Hannah More (Vol. 1, p. 155). New York: Harper.
} 
only ornamental landscapes but also functional. The design of park and countryside could be appreciated as a whole. It has recently been argued that this holistic perspective of the landscape should be interpreted as part of neo-classicism more broadly, to include Brownian landscapes alongside art and architecture, particularly as Brown designed many classical buildings and conceived of his parks as 'art'. This explains why Brown sought purity and clarity in his designs, and avoided the iconography represented in the copious ornamentation in gardens of previous generations. ${ }^{20}$

It has been argued that the naturalistic style of Brown's landscape was a response to the enclosure movement, which was not only extending the area under cultivation at the end of the eighteenth century but rationalising its form into large, 'improved' rectilinear fields. ${ }^{21}$ However, Brown's landscapes were as reliant on drainage, grazing, and planting as the working landscape and since the owner likely owned, invested, and intervened in the wider surrounding estate landscape a more complex set of relationships seems to be at work. More compelling must be the ideology that bound together the upper reaches of society - a belief in the right to rule, an engagement with the new capitalistic enterprises that were opened up by global commerce, and a set of aesthetic preferences that demonstrated their taste and education. By capturing these aspirations, Brown secured his position as one of the most influential landscape designers of the eighteenth century, when Britain was changing radically from an agrarian to an industrial nation and was asserting itself as a global power at a time when Europe was periodically convulsed by war and revolution. His creations came to define the 'polite' in a rural context at a critical time which saw the newly invigorated landed elite invest in landscape design on an ambitious scale.

There were key markers of Brown's success. First was his appointment as royal gardener in 1764. He had already been in practice for more than twenty years, working primarily with reliable foremen to execute work in various parts of the country. In 1762 he had taken on Samuel Lapidge as a pupil, but the demands of the new job required immediate assistance, employing John Spyers as a draughtsman. The job came with a house (Wilderness House) in the gardens at Hampton Court, and he took further premises on Hampton Court Green, a short walk away, where his offices were based. His new position had been gained as a result of recommendations from the nobility, who had lobbied for him, but in doing so he displaced the incumbent, Robert Greening, and evoked envy within the Office of Works that administered the management of the king's projects. His appointment as a royal gardener had confirmed his status as the leading gardener, and, besides his duties, he had the privilege of continuing his own business. Although the constitutional power of the crown was limited, particularly compared to France, for example, the royal imprimatur was still a lucrative badge of honour and opened access to a wide range of the richest patrons connected with the court. Perhaps the most telling indication of the value attached to royal patronage was Brown's successor Humphry Repton's subsequent frustration at not being admitted into the rarefied circles of court in the early-nineteenth century, as he sought to emulate Brown.

The second marker was Brown's purchase of the 1,000-acre Fenstanton manor, Huntingdonshire, a few years later in 1767. The purchase is usually interpreted as confirmation of Brown's wealth and as cementing his gentry status as a landowner. He paid a reduced rate for the manor, as he negotiated the purchase from the Earl of Northampton, who owed him money for the ambitious landscaping scheme at Castle Ashby. However, Floud has recently argued that the purchase was less about signalling social status, which Brown already had, and more about securing a proportion of his wealth in a stable form of investment. ${ }^{22}$ Both his appointment as royal gardener and his purchase of Fenstanton had the advantage of bringing in a regular annual income: the equivalent of around $£ 1$ million per annum from the manor, and $£ 54$ million for his time as royal gardener. These streams of income and those from government bonds helped to ease the cash flow over the ebb and flow of private commissions, which might take decades to complete.

${ }^{20}$ Hunt, J. D. (2016). Brown and neo-classicism. Garden History, 44 (Suppl. 1), 18-27.

${ }^{21}$ Bermingham, A. (1986). Landscape and ideology: The English rustic tradition, 1740-1860. London: Thames and Hudson.

${ }^{22}$ Floud, R. (2016). Capable entrepreneur? Lancelot Brown and his finances Occasional Papers from the RHS Library, 14, 19-41 (pp. 34-36); (2019). An economic history of the English garden. London: Allen Lane (p. 101). 


\section{Legacy}

Brown died suddenly after collapsing on the doorstep of his daughter Bridget Holland's house in London after returning home from Lord Coventry's on the $6^{\text {th }}$ February 1783 (Figure 1.3). Horace Walpole noted in his diary, 'His great and fine genius stood unrivalled ... Those who knew him best, or practiced near him, were not able to determine whether the quickness of his eye, or its correctness, were most to be admired. ${ }^{23}$ Brown was in some ways the personification of 'polite society' - he had used his ambition and education to rise from unremarkable origins in rural Northumberland; he sought out and retained patronage at the very highest level, to become the friend and acquaintance of royalty and key figures in government and amongst the landed elite. Two of his sons went to Eton; one became an MP and another rose to become an admiral in the navy. Brown himself became a landowner and High Sheriff of Huntingdonshire, and Floud has calculated that he made payments amounting to around $£ 36$ million in today's value, to his wife, children, and wider family in anticipation of their legacies before his death. ${ }^{24}$

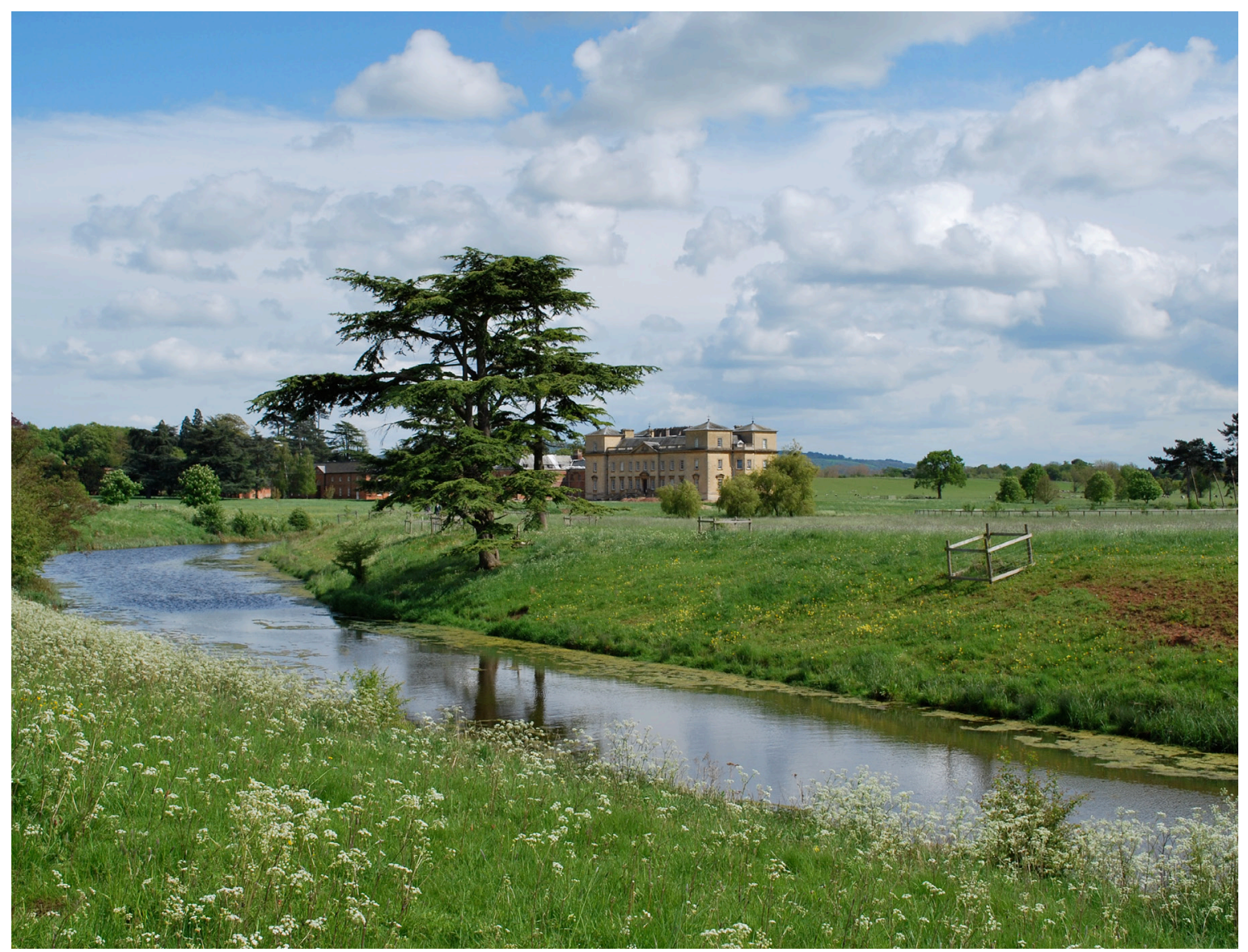

Figure 1.3: Croome Court, Worcs. Brown designed both the house and the landscape at Croome Court for his friend Lord Coventry, who coined Brown's sobriquet. Brown died suddenly in London having returned from a visit to his friend in February 1783. Photo copyright Jan Woudstra, 2009, CC BY-NC 4.0.

\footnotetext{
${ }^{23}$ Quoted in Stroud, D. (1950). Capability Brown (p. 200).

${ }^{24}$ Floud, R. (2016). Capable entrepreneur? Lancelot Brown and his finances (pp. 38-39).
} 
His obituary recorded his obvious intelligence, his amiability, and his ability to provide solutions for design problems, both quickly and efficiently:

His great and fine genius stood unrivalled, and it was the peculiar felicity of it was allowed by all ranks and degrees of society in this country, and by many noble and great personages in other countries. Those who knew him best, or practiced near him, were not able to determine whether the quickness of his eye, or its correctness, were most to be admired. It was comprehensive and elegant, and it may be said never to have failed him. Such, however, was the effect of his genius, that when he was the happiest man, he will least be remembered, so closely did he copy nature, that his works will be mistaken [for it]. His truth, his integrity, and his good humour, were very effectual, and will hold a place in the memory of his friends, more likely to continue, though not less to be esteemed. ${ }^{25}$

His position as a national celebrity had been recognised from the 1770s. In September 1770, for example, the Public Advertiser reported his appointment to remodel St. James's Park in London, and referred to him as 'Mr Brown, the Engineer, commonly called Capability Brown', but two years later the same paper described him as 'Mr Capability Brown, the great Arbiter of British Taste.". From the 1770s, and particularly in the decade after his death, his name had become a popular by-word for the naturalistic English landscape style. For example, in Charles Dibdin's Hannah Hewit: Or, the Female Crusoe, first published in 1792, the shipwrecked heroine sets about fashioning a garden around her tropical hut:

To be sure, no pleasure ground was ever laid out by capability-Brown with more grandeur or stocked with more beautiful shrubbery, than the splendid expanse both behind and before my house... ${ }^{27}$

However, Brown was no stranger to criticism during his lifetime, and his popularity at court brought him into conflict with the designer Sir William Chambers, who coveted Brown's royal position and launched a series of attacks on what he considered to be Brown's lack of imagination and education due, largely, to his lowly, common status. Chambers sneered at Brown as the 'petty architect' and the 'peasant' who had 'emerged from the melon grounds to take the periwig, and turn professors' and characterised Brown's work as 'gardens differing very little from common fields, so closely is vulgar nature copied in most of them; ... these compositions rather appear the offspring of chance than design; and a stranger is often at a loss to know whether he is walking in a common meadow, or in a pleasure ground. ${ }^{28}$ Brown and the large-landowning, improving patrons he served had been attacked by Goldsmith in his poem The Deserted Village, published in 1770, which identified emparking by the nouveaux riche as the cause of settlement desertion, whilst Brown was directly targeted in Cowper's poem The Task, published two years after his death in 1785, which referred to Brown pejoratively as the 'omnipotent magician' who could make a lake into a lawn, ' $[\mathrm{w}]$ oods vanish, hills subside, and vallies rise.29 During his lifetime Brown's powerful allies in government and at court rallied to his defence, but after his death the ubiquity of Brownian landscapes - especially those created by his imitators - and their predictable character, led to a growing chorus of criticism and inevitable backlash, which became the 'Picturesque Controversy' led by Uvedale Price and Richard Payne Knight.

The idea of the Picturesque is deeply rooted in relationships between image or representation of landscape and the physical landscape, but it gained new meaning and new importance in the late-eighteenth century. Brown had readily embraced his own sense of those relationships and created points within the landscape where framed views were presented, but overall it was the informal presentation of the landscape, the placemaking', that differentiated Bridgeman, Kent, and, latterly and most significantly, Brown from the earlier continental orthodoxy of geometric, structured, formal gardens. It could be argued therefore that Brown was the

${ }^{25}$ Anon., 'Thursday morning, Feb.6, 1783, about nine o'clock, died Lancelot Brown', Morning Chronicle and London Advertiser, 8 February 1783.

26 Anon., 'Mr Brown, the engineer, commonly called Capability Brown', Public Advertiser, 6 September 1770, Issue 11126; Anon., 'Mr Capability Brown, the great arbiter of British taste', 9 September 1772, Issue 11097. When Brown surveyed the finished lake at Blenheim, he allegedly remarked 'Thames! Thames! thou wilt never forgive me this!'

27 Dibdin, C. (1796). Hannah Hewit: Or, the female Crusoe (Vol. 3, p. 68). London.

${ }^{28}$ Chambers, W. (1773). A dissertation on oriental gardening (p. 13). London.

${ }^{29}$ Cowper, W. (1785). The Task, a poem, in six books (III) (p. 775). See also: Marshall, W. G. (1987). The presence of 'The Word' in Cowper's The Task. Studies in English Literature, 1500-1900, 27(3), 475-87. 
necessary precursor of the Picturesque, in which it was the painter's eye, the image, which framed the landscape and was bound to artistic rules and conventions. At the heart of Price and Payne Knight's critique was a rejection of Burke and Brown's Beautiful, with smooth and elegant curvilinear lines, and a shift towards the rough, irregular, asymmetrical landscapes of the sublime. The Picturesque critique of Brown was personalised and sharp. Knight's didactic poem The Landscape, published in 1794, referred to Brown as the 'Thin, meagre genius of the bare and bald', whilst Price's Essay on the Picturesque drove the assault home, critiquing, amongst other aspects of the Brownian landscape, the bare banks of his 'naked canals' or lakes where 'nothing detains the eye a moment. ${ }^{30}$ Price advocated the supremacy of the painter's eye, though he defined a painter widely as 'any man (artist or not) of a liberal mind, with a strong feeling for nature as well as art, who has been in the habit of comparing both together'. A painter, he argued, would look on clumps, belts, 'made water', and 'the eternal smoothness and sameness of a finished place' of the improver with 'indifference, if not with disgust." ${ }^{31}$

It would be fair to say that the assault on Brown was based on a peculiarly broad and ill-defined perception of his work and did not allow for the fact that Brown's style evolved over his career. The target was the repetitious, predictable, and ubiquitous landscapes that followed Brown's style. Brown's posthumous champion in the controversy was Humphry Repton (1752-1818), the landscape gardener, who, when he set up in business aged 36 in 1788, declared that 'the work of Kent, Brown and Richmond have been the places of my worship'. Repton defended Brown in a published letter which was later appended to Sketches and Hints on Landscape Gardening (1794) and in doing so opened himself to the same misrepresentative and personal attack which had been launched on Brown. However, Repton's measured and ameliorative response, which argued rationally for the distinction between the landscape and the image, and the necessity of working with the former rather than the latter as a landscape gardener, arguably won the day in the longer term. But Price and Knight presaged the coming of the gothic and a new definition of a national vision for landscape that, drawing on Gilpin, embraced the romantic and the ruined remnants of the medieval past, and interest in or celebration of Brown's work dwindled. However, it is clear that Repton kept Brown's ideas in the public eye at the very end of the eighteenth century, and the landscape gardener J. C. Loudon's publication of Repton's collected works in the mid-nineteenth century not only brought Repton's landscape style to a new audience, but the widely translated texts belatedly spread Brown's legacy across continental Europe, where English gardens were a feature of many nineteenth-century designs, albeit seen through the eyes of Repton. However, there were those that continued to perpetuate the Picturesque critique of Brown, such as the founder of American landscape design and advocate of the Gothic Revival, Andrew Jackson Downing (1815-52), whose Treatise on the Theory and Practice of Landscape Gardening (1841) quoted extensively from Knight and added that Brown had 'once disgraced half the finest places in England with his tame bald pieces of artificial water, and round, formal, clumps of trees. ${ }^{32}$

It is often asserted that the modern revival of Brown's reputation began with Dorothy Stroud's biography, first published in 1950. ${ }^{33}$ However, Stroud's book had been stalled by the outbreak of war in 1939, and published references to Capability Brown pick up significantly over the 1940s, before Stroud's biography was published. Brown's vision of rural England was recruited to support morale on the home front, as it was seen to capture the nostalgic essence of Englishness: Brown's imagined landscape of England around the country houses was a powerful tool. However, the post-war period saw the loss of many country houses and their landscapes due to death duties and those that survived were at risk as government and planners set about building the new modern Britain exemplified by the 1951 Festival of Britain. ${ }^{34}$

Today, Brown is the only individual to be recognised with a blue plaque (an historical marker) as a 'landscape architect' on his former residence at Hampton Court Palace, where he lived whilst royal gardener to George I (Figure 1.4). In the afterglow of 'Brown 300' (2016), a year-long celebration of Brown's contribution to the English landscape in 2016, he is once again celebrated as the main proponent of the 'English landscape garden', yet what that entailed, and the extent and nature of his influence, continues to be fiercely debated, particularly within a wider European context. Brown's legacy remains contested even after the celebration of

\footnotetext{
${ }^{30}$ Knight, R. P. (1794). The landscape: A didactic poem in three books (Vol. I, p. 284). London; Price, U. (1796). An essay on the picturesque (p. 251). London.

31 Price, U. An essay on the picturesque (p. 9).

32 Downing, A. J. (1841). A treatise on the theory and practice of landscape gardening, adapted to North America: With a view to the improvement of country residences (p. 279). New York and London.

33 Stroud, D. (1950). Capability Brown.

${ }^{34}$ Cornforth, J. (1974). Country houses in Britain - Can they survive? London: Country Life.
} 


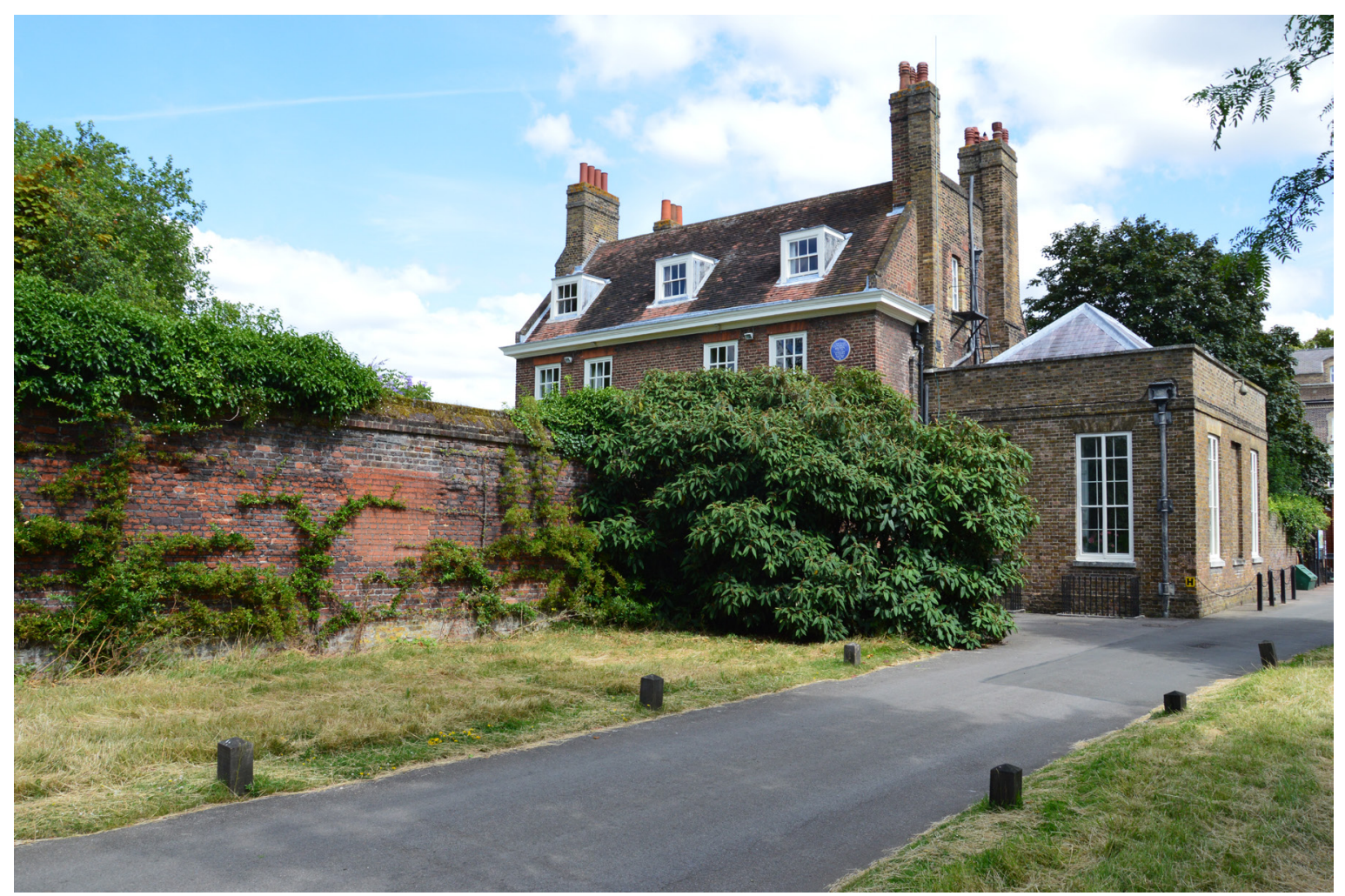

Figure 1.4: Wilderness House. Brown is the only 'landscape architect' to be recognised with a 'blue plaque' as a commemorative historical marker. It is on Wilderness House, his former residence at Hampton Court Palace. Photo copyright Jan Woudstra, 2016, CC BY-NC 4.0.

his $300^{\text {th }}$ anniversary, which saw an unprecedented amount of research and public engagement into his life and sites. There are those who consider him to have been the genius of landscape design at a time when the practice and politics of landscape was at its height. And there are those who argue that his vision of place-making drew heavily on elements and ideas that other designers had already experimented with, in reaction to formal landscape designs, and that it was his business success that made him stand out. However, Brown undoubtedly changed perceptions of what became an English landscape style and he was personally synonymous with it and its reiteration. Brown was undeniably a celebrity of his day, feted by the influencers of national taste, indeed considered to be the chief arbiter of taste, and the designer of choice for those with the resources to implement his schemes over estates and parkland. In capturing or crafting the requirements of the ruling landed class at an historical moment when they were arguably at their greatest power, Brown and his landscapes have a lot to tell us about social relationships within the changing rural landscape and the articulation of power in the lateeighteenth century, when the nation was in the ascendency as a global power.

This book addresses three main areas which have been neglected in studies of Brown and the eighteenthcentury landscape: his role as royal gardener, his working methods and contemporaries, and his impact abroad. His position as royal gardener brought him prestige and clients to develop his reputation, crucially placing him within the world of nurserymen and landscape designers, many of whom lived and worked around Hampton Court Palace, where Brown was based. His business practice of recruiting and retaining a well-paid circle of workmen, draughtsmen, and designers allowed him to manage a huge number of projects and a substantial financial turnover, which in turn allowed him to work in a manner and to an extent that no contemporary could match. It also brings together a number of perspectives from across Northern Europe, as far as Catherine the Great's St. Petersburg in Russia, where she was one of the first to remodel her landscapes to reflect the new 'English' style with which Brown's name became synonymous. This book therefore draws on historical studies, art history, and archaeology to increase our understanding of Brown, his business, and his legacy. 


\section{Chapter Structure}

In the next chapter, David Jacques provides a compelling account of Brown's career as His Majesty's Chief Gardener at Hampton Court. Brown had failed to secure the post of His Majesty's Chief Gardener at Kensington Gardens in 1757; however, by 1764 the king had been forced to accept George Grenville as Prime Minister. He knew Brown from his work at Stowe and placed him at Hampton Court. Brown's arrival at Hampton Court was not universally welcomed, and various difficulties were put in his way. Support from the Treasury and professional rivalries led to extremely poor relations between Chambers and Brown. Chambers had the Board of Works admonish Brown in 1770 for supposed neglect, and followed that up with his book, Dissertation on Oriental Gardening (1772), in which he referred to Brown amongst 'Peasants [who] emerge from the melon grounds'. However, the two sparring partners learned to desist and Brown remained Chief Gardener until his death. Brown is sometimes credited, on the basis of his proposal plans, with designing the gardens at the Queen's House (later Buckingham Palace) and re-designing St. James's Park. This was not carried out, but he was commissioned to re-form Richmond Gardens, owned by the king as his personal property, in 1764.

Remaining at Hampton Court and within the circle of court patronage, Sebastian Edwards provides a portrait of John Spyers of Hampton Court. Spyers was one of Brown's two lieutenants when he arrived at Hampton Court. He was a prolific surveyor, helping Brown improve dozens of landscapes, who would be largely overlooked were it not for his exceptional achievement of creating 100 drawings of his home and workplace, Hampton Court, and their improbable sale to Catherine the Great, Empress of Russia. Unlike his business partner Lapidge, he left little mark on other landscapes and we have to scour accounts, legal papers, and his own drawings to attempt a biography. The creation of a Hampton Court album appears to have been an act of artistic self-improvement, rather than a survey commissioned for Brown. The accompanying album of designs for garden buildings and landscape capriccio views provide valuable insights into the working practice in Brown's office, but also begs questions about the complementary roles of designer and draughtsman - an area still poorly understood. The album's sale at the time of Brown's death through the intermediary of gardener James Meader (who also worked for one of Brown's great clients) indicates the sale was opportunist. Following Brown's demise, and encouraged by artists in his family, Spyers abandoned gardening and set up as a topographical artist. Exhibiting at the Royal Academy and publishing etchings of Hampton Court helped to attract a local clientele of gentlemen house-owners and even the king himself, as revealed by recent discoveries.

Matthew Storey interrogates topographical views of the royal gardens at Kew and Richmond, made at the time of their development in the 1760s and 1770s, as historical sources. The features of the two royal gardens have almost entirely been lost through subsequent alterations of the site that is now the Royal Botanic Gardens, Kew. Storey examines the extent to which the original appearance of the gardens can be understood through visual sources, including maps, topographical prints, and paintings, and whether the views can tell us about the very different ways the gardens could be perceived at the time. Chambers published his Plans, Elevations and Perspective Views of the Gardens and Buildings at Kew in Surry [sic] in 1763, after designing a series of buildings in Kew Gardens. He claimed that 'what was once a Desert is now an Eden', but the views he published may have presented an intended, rather than an attained, Eden. Many of the topographical views of Kew present Chambers's buildings in a mature landscape. Yet this was a garden that had rapidly developed on land described by Chambers as having 'so many disadvantages it was not easy to produce anything even tolerable in gardening? By mapping views by a range of artists, including Richard Wilson, onto plans of the landscape Storey evaluates the extent to which the artists drew what they actually saw, or rather created a narrative about the garden. In contrast, far fewer views of Brown's work at Richmond Gardens survive or were made. The views we have focus on the river landscape and the view across the water to Brown's existing landscape at Syon House. This view was already celebrated by artists before Brown started work, and suggests the aesthetic he was working within. Analysis of the evidence of views and plans of Richmond Gardens can help us to understand Brown's intentions and work carried out in this royal garden.

Moving away from the metropole and Brown's position at court, Tom Williamson maps out the Brown business model and his role as an improver. Brown was the head of a complex business which could supply clients with a whole design 'package' embracing far more than the just the landscape parks which we normally associate with his name. This might include - in a surprising number of cases - a new or improved house. It frequently involved the creation of menageries, gardens, and pleasure grounds, the construction of stables, outbuildings, and ice houses, and the provision of kitchen gardens and even of such mundane features as 
drying yards. The activities of his team usually, on heavier land, included the installation of complex land drainage schemes. Our traditional focus on the 'landscape park' has arguably led us to underestimate the importance of these other 'improvements', but without an appreciation of their significance, the character of his parkland landscapes cannot itself be fully appreciated. This chapter describes the nature and organisation of Brown's business, and the careers of some of its principal members, before examining what precisely it supplied. It draws comparisons with similar providers of 'taste' in the 1760s and 1770s - the Adam brothers, Chippendale, Wedgwood - and addresses the significance, in social and ideological terms, of neo-classical ideas applied to domestic design.

Jonathan Finch presents a detailed case study of how Brown managed sites at a distance from his base in the metropole. Brown worked and consulted across the country, building his reputation and business model as he went. One of his most successful landscapes in Yorkshire was created around the newly commissioned Harewood House in West Yorkshire, a site he first visited in 1758 before construction had begun. The design took full advantage of the local topography and retains much that is quintessentially Brown, particularly the lake, which initially proved so troublesome to establish. However, the detailed examination of accounts and letters reveals how other designers were also involved at the site, as were some of Brown's associates and foremen. The two greatest challenges that the situation of the new house presented were the 'hill' on the north front, which had to be 'scrapped back', and to the south, where Gawthorpe Hall stood for around four years after the new house was completed, between the new house and Brown's lake. Excavations on the site of the medieval hall have revealed how the house was removed and landscaped to connect the new house and water. Understanding the development of the landscape at Harewood, from before Brown's visit to Repton's interventions in the early-nineteenth century, places Brown within complex networks of patronage and employment as well as demonstrating the enormous logistical challenges that landscape designers had to overcome to realise their visions.

Jan Woudstra explores Brown's legacy on landscape practice through the case study of Chiswick House and how it was managed by Samuel Lapidge after Brown's death. In doing so Woudstra provides a detailed exposition of how Brown's business operated at site or commission level, since, although there is now a general understanding of how Brown worked, there is little information on how exactly his practice was run, where decisions were taken and by whom, and how work was proposed and executed. There are also limited examples where the relationships between client, agent, designer, foreman, and suppliers have been studied. To enable us to extract some answers to these questions and increase our understanding about the question of authorship, it is necessary to look in depth at specific cases. Chiswick House illustrates how a small contract was run immediately after Brown's demise and would presumably have been run before it. Detailed accounts of work executed for the $5^{\text {th }}$ Duke of Devonshire at Chiswick immediately after Brown's death are revealing of the practice as it continued under Samuel Lapidge, assisted by William Ireland. Contracts, drawings, inventories, bills, and vouchers covering the period $1784-85$ provide a basis for analysis that illuminates the manner of working, the general practice of Brown's office, and attributions. Lapidge emerges as an important figure and Woudstra looks at his origins; his early work for Brown; how he - and not Spyers - became Brown's most trusted associate; and finally at Brown's injunction to him to finish the contracts and his attempt to perpetuate the business, though with limited success.

David Brown profiles Nathaniel Richmond, another star within Brown's circle of trusted associates who, according to Elizabeth Montagu, was 'Mr. Brown's best élève', whilst Repton mourned his death and ranked him alongside William Kent and Brown. Had Richmond not died within a year of Brown, he would arguably have been his natural successor in the south of England, and yet he is now virtually unknown. Between 1740 and 1790, the improvement of gardens, parks, and estates became a rapidly expanding business employing an increasing number of people. The cohort of improvers born in the first decades of the century, including Brown, Woods, Emes, Richardson, Richmond, Donn, Sanderson, Mickle, and White, would power this expansion. Richmond's story could, in many ways, be the story of any of them. Richmond was born c. 1719 and died 'in his $65^{\text {th }}$ year' in February 1784 as a result of an infection following an accident during a site visit. By 1749 he was living at Tardebigge, on the Hewell Grange estate, where both he and Brown would later work separately, and he supplied forest trees to Walter Gough of Perry Hall. In 1754 he received payments from Brown, recorded in Brown's bank account with Drummonds, and lived in Rickmansworth, adjacent to Moor Park. Richmond then established a nursery on the Portman Estate in Marylebone in 1759. For the next twenty years or so he ran a very successful improvement business working on parks and pleasure grounds both for the 'big city bourgeoisie' and for aristocratic clients. David Brown analyses several surviving eighteenth-century 
bank ledgers for the period 1760-84 as the central plank of his research to identify further clients of Richmond as well as revealing payments to some of his contemporaries.

In contrast to Woudstra and Brown, Val Bott explores a well-established family of nurserymen - the Greenings of Brentford End, who enjoyed royal and aristocratic patronage from the 1720s into the 1760s, but who were ousted by Brown. Thomas Greening the Elder had established a nursery in Isleworth by about 1710, and he also took on garden works for aristocratic clients, winning a royal patent for his method of grafting elms in 1724. Collectively the Greenings worked for the royal family at Kew, Richmond, Hampton Court, Kensington, and St. James's Park from the 1720s to the 1760s, far longer than Brown. Thomas's eldest son, also Thomas, was groomed to be his father's successor and worked with his brother, Robert, who in about 1750 was commissioned to re-design Wimpole Park, work that was largely undone by Brown in the 1760s. In 1753, however, Robert became head gardener of the royal pleasure grounds at Kew for an annual fee of 300 guineas plus the use of fifty-four acres of farmland there. The second son, John, was gardener to the Duke of Newcastle at Claremont in the 1730s and 1740s. He obtained the royal contract for Kensington Gardens in 1758, despite rival support for Brown and largely because of the support of the Duke of Newcastle, then Prime Minister. However, John was ousted from Hampton Court in favour of Brown in 1764 through the influence of the Grenvilles of Stowe. Using correspondence and contracts, deeds, wills, and contemporaries' descriptions, Bott's chapter provides the first detailed family biography of the Greenings, exploring their reputations and styles of work, family relationships, and networks of business and friendship.

Kate Felus argues that there is no better way to understand and interpret Brown's work than to know how his clients used his designs. While recently there has been much research on the practical nuts and bolts behind Brown's working practice, and that of his contemporaries and 'imitators', there is still a tendency to see his works theoretically, in terms of aesthetics. A visit to a Brownian landscape today often entails a drive through parkland where the only signs of life are the grazing sheep. This is a long way from the state of things during the eighteenth century. Brown's designs were created to be used and enjoyed, and were frequently teeming with life. To a great extent, form followed function. Brown was, of course, a water engineer par excellence, and there are several examples of boats being built for lakes, just as the lake was being created, suggesting that the pleasure of boating was a major reason for the creation of the water body. Felus discusses a number of common contemporary uses within Brown designs, including boating, carriage driving, and dining, and how understanding those uses can help us interpret the landscapes today.

Brown's impact in continental Europe is examined through case studies from Germany, the Netherlands, and France. Prior to the mid-eighteenth century Britain had drawn much of its landscape inspiration from Europe, and Brown and his contemporaries are often cited as making a decisive break with the European tradition of formal gardens to create the naturalistic English landscape style. This was then exported back to Europe, with early enthusiastic supporters such as Catherine the Great in Russia, as the jardin anglais. However, what was meant by the term and whose ideas it captured has not been critically examined. Repton was certainly a key conduit for spreading the idea of a Brownian landscape.

Michael Rohde highlights Brown's influence on the development of the landscape garden in Germany. In spite of criticism of his homogenous designs, both in England and Germany, Brown affected the so-called 'classical landscape garden' during the late-eighteenth century, while the later compartmentalisation of the Reptonian style remained popular into the nineteenth century. The landscape gardener Friedrich Ludwig Sckell, who visited England from 1773 to the end of 1776, and met both Brown and Chambers, studied landscapes such as Blenheim, Stowe, Stourhead, and Kew before designing some of the most important parks in Germany. Later he wrote his treatise Beiträge zur bildenden Gartenkunst [Contributions to Creative Garden Art] (1825), which was published in instalments by his English admirer John Claudius Loudon. Another traveller, Prince Pückler-Muskau, who studied Brown's improvements at Blenheim and Longleat, was impressed by his natural style and creation of lakes. In his own gardens at Muskau and Branitz he shared these classical principles, as well as the spatial zoning of Repton. Eduard Petzold, who became the garden director at Muskau to Prince Frederick of the Netherlands, continued these 'landscape' principles but developed his own form and aesthetics concerning planting. Thus there were three very distinct types of landscape gardens in Germany, clearly showing their roots. Rohde then looks at the case of Peter Joseph Lenné, the nineteenth-century general director of the Prussian royal gardens, whose work is still visible at Charlottenhof and Sanssouci at Potsdam. By the early-twentieth century most parks had become overgrown and required extensive clearance. In his 1927 study on the landscape garden in Germany, the art historian Franz Halbaum was one of the first to highlight the 
work of the garden director Georg Potente in Potsdam-Sanssouci as exemplary. Today it is still possible to see the pioneering garden conservation methodologies developed then, particularly in Charlottenhof.

Jan Woudstra and Willem Zieleman explore the notion of the English garden in the Netherlands, observing how actual examples were often developed from the bosquet a l'angloise, a Batty Langley-type wildernesses with serpentine paths and graduated shrub planting. By looking at the case study of Het Loo Palace, Apeldoorn, various stages of the development of the jardin anglais can be observed, with some of the main impetus being provided by German and French designers. The large scale of English Brownian landscapes was not appropriate to the intricate scale of the Dutch landscape, and it was Brown's concepts mediated through Humphry Repton that came to represent the principal English influence, both by being adopted by some of the main designers and by actual examples of gardens designed by Repton's son John Adey. By the late-nineteenth century the Dutch landscape designer Leonard Springer relaunched and popularised the Brownian style as the landscape style', and the 'English garden' and the 'landscape garden'. This led to new interpretations of the origins of the style and was adopted into the predominant phyto-geographical and ecological narratives of post-war reconstruction, becoming a starting point for modern landscape architecture.

Laurent Châtel and Monique Mosser emphasise the fact that, though there were several phases of anglomania in France during the eighteenth century, particularly in the 1750s and 1770s, Brown's name only infrequently occurs within the examples of the jardin anglais established in France during this period. In fact, Chatel and Mosser observe how there are very few mentions of Brown's name during his lifetime, despite the fact that there are some early examples of Brownian transformations of gardens. After 1784 he was incorporated in French historiographies as a marker of the evolution of the English garden within the sequence between William Kent and Humphry Repton, while others accused Brown of a corruption of taste within the Picturesque debate. The evidence of Brown's legacy in France was not so much documentary as in the examples of Brownian gardens that survive and the ways his style has been adapted.

The idea for this book was generated at a conference held at Hampton Court Palace in 2016, which was a collaboration between Historic Royal Palaces and the Universities of East Anglia, Sheffield and York. Since then it has grown and developed in response to the ongoing research into Brown and his times. It is the first volume to be produced on Brown since the celebration of his tercentenary in 2016 and since the bicentenary of Humphry Repton, Brown's successor in the art and science of landscape architecture, in 2018. Both events reignited and reorientated interest in designed landscapes over the critical period of the late-eighteenth and early-nineteenth centuries and the debates around their merit and significance, both then and now. These debates now spread across archaeology, art history, history, design, philosophy, and literary studies - and engage with issues from green spaces and well-being to gender and class. As such the history of designed landscapes is now firmly established as an integral part of cross-disciplinary research into the legacy of the past on our lives and how we live now.

\section{Select Bibliography}

A select bibliography is available at the end of this volume, or at: https://doi.org/10.22599/CapabilityBrown.o. 